\title{
Great Pyrenees
}

National Cancer Institute

\section{Source}

National Cancer Institute. Great Pyrenees. NCI Thesaurus. Code C53766.

The Great Pyrenees is a very large animal with a solid muscular body. The long, coarse, outer coat is either straight or slightly wavy, while the undercoat is soft and thick. Coat colors come in solid white, or white with patches of tan, wolf-gray or pale yellow. The medium-sized ears are triangular and pendant. Height: 25-32 inches $(63-81 \mathrm{~cm}$.). These are the average heights, but some Pyrenees are as much as 40 inches (1 meter) Weight: from 85 pounds (38kg.) 